\section{New directions, new faces for science following US elections}

Washington, Berkeley \& Boston

THE transition between the Reagan and Bush administrations has begun with the announcement that Mr James Baker will be the next Secretary of State. Beyond that, the Bush transition team has made no detailed pronouncements about the direction in which the new administration will go, or whether there will be changes in support for science. But the results of elections for membership of Congress ensure that several key figures in science policy will disappear from the national scene.

President-elect Geoge Bush seems set to continue President Ronald Reagan's strong support for 'big science' projects, such as the Superconducting Super Collider (see page 195) and the space programme. He has supported the plans initiated by the Reagan Administration to double the budget of the National Science Foundation, but appears less zealous than Reagan in his support for the Strategic Defense Initiative.

The Democrat-controlled Senate faced by Bush will begin its next session lacking three members who played key roles in guiding science policy. Democrat William Proxmire of Wisconsin retires from the Senate, where he had been chairman of the subcommittee overseeing the budget of the National Science Foundation.

Proxmire was known for his efforts to staunch the flow of government dollars to wasteful projects. He awarded a 'Golden Fleece' award to particularly egregious examples of waste, although the awards often rankled with researchers who felt they were unfairly attacked.

Florida Senator Lawton Chiles (Democrat) announced earlicr this year that he would not run for re-election. Chiles had been chairman of the appropriations subcommittee responsible for the budget of the National Institutes of Health. Also missing will be Republican Lowell Weicker of Connecticut who lost an extremely close race to Democrat Joe Lieberman. Weicker had been an active supporter of biomedical research, and had a strong interest in ocean research.

Congress will take note of public feeling expressed directly at state ballots on a number of science-related issues. Californians split their votes on two measures involving AIDS. One, that would have required notification to public health officials of anyone testing positive for antibodies to the AIDS virus, was rejected by 66 per cent of the voters, although polls taken several months ago had indicated it would pass (see Nature 335, 386; 1988). The proposition received the support of California governor George Deukmeijian, but was opposed by most Californian medical associations.

A second initiative calling for AIDS testing of accused criminals that received far less publicity passed by a 62 to 38 per cent margin. It allows the victims of sex crimes, as well as police officers, firemen and emergency medical personnel who are bitten, spat on or otherwise exposed to bodily fluids during an assault, to request that the accused assailant be tested for human immunodeficiency virus.

Despite a well-financed campaign by the tobacco lobby, Californians voted to increase the tax on a package by 25 cents. In Oregon, a measure that would have

\section{IMAGE UNAVAILABLE FOR COPYRIGHT REASONS}

The president-elect in less than zealous mood? banned smoking in most indoor public places went down to defeat

In Massachusetts, voters soundly rejected a referendum question that would have shut the state's two nuclear power plants (see Nature 336, 3; 1988). The vote was 32 per cent for the measure, 68 per cent against. The measure's supporters blame the scale of their defeat on the fact that the opposition, organized by regional utility companies, raised over $\$ 7$ million in campaign funds, more than twenty times the money raised by the measure's proponents.

Three states passed measures that will make abortions more difficult to obtain. Those in Colorado and Michigan forbid the use of state funds to pay for abortions. In Arkansas, voters adopted the so-called Unborn Child Amendment, which could have the effect of forbidding all abortions in the state. The act's full impact will be felt if the Supreme Court reverses its landmark decision that made abortions legal, as it may do during its current term.
Reactors on order despite accusations Washington

In the wake of a series of accidents and charges of mismanagement at existing facilities, plans to construct two new reactors to produce tritium needed for nuclear weapons are "moving forward on a fast track", a Department of Energy (DoE) official said last week. But even under the best of circumstances it will be "ten years before the reactors will be on-line". Troy Wade, acting assistant secretary of the DoE's defence programmes, said that work should begin within two years on construction of a new heavy-water reactor and a modular high-temperature gas reactor capable of producing tritium. The new facilities will replace ageing reactors at the Savannah River Plant in South Carolina, none of which is currently operating.

Wade said DoE expects the Department of Defense to provide the $\$ 6,800$ million needed for the reactor programme, and predicted there would be some interagency bickering over the issue. The programme must also get congressional approval. Wade said that the United States is, for the first time, living off its "working reserve" of tritium and if production does not start up again soon the situation will become critical. Lisa Perlman

\section{Neural networks programme to start}

\section{Washington}

A MAJOR new research programme to develop artificial neural network computers will be launched by the US Defense Advanced Research Projects Agency (DARPA) this month. The programme begins by providing almost everything that was asked for in a report commissioned by DARPA and published three months ago.

For the first 17 months of the programme, $\$ 33$ million will be available for research aimed at assessing the advantages of neural-network computers in complex information processing and control systems, developing new modular hardware to make it easier to build large neuralnetwork computers and advancing theory to determine the limitations of neuralnetwork systems.

That will take the programme to the end of fiscal year 1990, beyond which DARPA is not yet able to commmit itself. The report to DARPA asked that initial funding of $\$ 40$ million be followed by increases which would provide a total of $\$ 400$ million for a programme running until 1995. Evaluation of progress will centre on the success of neural-network computers at three tasks of great interest to the Pentagon: automatic target recognition, continuous speech recognition and sonar signal identification. Alun Anderson 